\title{
ORGANIZATION OF TECHNICAL RESCUE OPERATIONS IN THE NATIONAL RESCUE SYSTEM
}

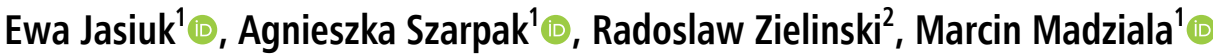 \\ ${ }^{1}$ Lazarski University, Warsaw, Poland \\ ${ }^{2}$ Polish Society of Disaster Medicine, Warsaw, Poland
}

\begin{abstract}
The organization of technical rescue is crucial to carry out an effective rescue operation. Often, this field of rescue is an inseparable element when conducting medical rescue operations, where it is necessary to use highly specialized equipment that is designed to provide access to the injured person and enable members of the Emergency Medical Teams to conduct medical rescue operations, as well as to provide them with qualified first aid by firefighters.
\end{abstract}

KEY WORDS: technical rescue, specialized rescue, State Fire Service (PSP), Volunteer Fire Brigade (OSP), National Fire and Rescue System (KSRG)

Disaster Emerg Med J 2019; 4(2): 63-67

\section{INTRODUCTION}

Increasingly occurring mass events, natural and technological disasters are the domain of densely populated areas, causing an increasing number of fatalities and injuries, economic losses, social problems as well as environmental damage [1]. Technical rescue, in addition to emergency medical services, is an integral part of helping injured parties with transport, construction or disaster events and natural disasters. The use of necessary equipment and equipment in this field requires from people operating them the appropriate practical and theoretical preparation, as well as structural solutions that aid in the organization of this form of rescue. Technical rescue in the territory of the Republic of Poland is carried out by entities of the National Fire and Rescue System in the primary and specialist scope. The activities of the Specialist Technical Rescue Groups outside the country hinder on the applicable provisions per signed agreements and methodological instructions. KSRG in the field of technical rescue includes planning, organizing and carrying out res- cue operations necessary to search for and reach endangered or injured people and animals, as well as reduce or eliminate threats to life, health, property or environments [2]. Every life-endangering event, especially one requiring the involvement of many services and rescue entities is undoubtedly a crisis. In crises, an active attitude of all participants in the fight against emerging threats is necessary. Very often, however, this is not enough, and it is necessary to use specialized equipment that is provided by the entities participating in the activities [3].

\section{The primary scope of the technical rescue organization}

The necessary scope includes rescue operations performed by all fire and rescue units of the State Fire Service, as well as other fire protection units or rescue entities declaring operational readiness the ability to perform tasks according to their organizational and hardware capabilities and training, in a 24-hour and all-year system. The development of technical rescue should take place in such a way that the 
ability to carry out rescue operations at the primary level becomes common to all entities of KSRSG. The qualification requirements for performing technical rescue tasks at the primary level are as follows [4]:

a) the technical rescue operations in the primary scope are carried out by firefighters with technical rescue skills acquired as part of the qualification training and reinforced as part of professional development;

b) PSP firefighters, who did not have the opportunity to obtain technical rescue skills as part of the qualification and professional training, should obtain them as part of complementary training;

c) the members of OSP units designated for technical rescue tasks should acquire skills in the field of technical rescue as part of the training system for OSP members participating in rescue operations;

d) professional development skills in technical rescue should include training:

- in the field of servicing technical devices used in technical rescue,

- from the scope of the rights required by other regulations related to the use of specialized technical equipment (cranes and hook permits);

e) training should ensure obtaining "hook" qualifications in the number necessary to maintain the continuity of rescue operations in the case where the unit in the primary scope has equipment for which it is advisable to have such qualifications. f) Training should ensure that qualifications are obtained to conduct activities within the scope of qualified first aid in the number necessary to maintain the continuity of rescue operations [5]. Technical rescue in the primary scope is carried out by all fire and rescue units of the State Fire Service, fire protection units, and in particular, OSP. KSRG declares its operational readiness, the ability to carry out these tasks according to their organizational, equipment capabilities and training, as well as other rescue entities cooperating with KSRG. KSRG also declares their operational capability to perform these tasks according to the possessed organizational and hardware capabilities and training [6].

The Table 1 presents a summary and minimum standards for equipment and technical rescue measures for basic emergency operations. The technical rescue in the primary scope of the KSRG organized by the territorially competent district commander or municipal PSP, including cooperation with the OSP as well as other rescue entities and services obliged to conduct technical rescue operations (Fig. 1-3). Tasks implemented as part of technical rescue in the primary scope is as follows:

a) diagnosis and assessment of risks for:

- life and health,

- environment and property;

b) help for imprisoned people by reaching victims or endangered people and granting them quali-

\begin{tabular}{|c|c|c|}
\hline Nr. & Equipment & Quantity \\
\hline 1 & Arm splitter with accessories (2 chain locks, 2 chains with hooks) & 1 \\
\hline 2 & Hydraulic cutting shears 1 & 1 set \\
\hline 3 & $\begin{array}{l}\text { Expanding cylinders with a set of interchangeable tips (cross, wedge, conical) of } \\
\text { various lengths }\end{array}$ & 2 sets (various lengths) \\
\hline 4 & Power unit for hydraulic tools about the work model min. & 1 \\
\hline 5 & A set of hydraulic hoses, min. 5 meters & 2 sets \\
\hline 6 & High-pressure pneumatic lifting cushions with a lifting capacity from $50 \mathrm{kN}$ to $300 \mathrm{kN}$ & $2(Z)^{*}$ (with different load capacity) \\
\hline 7 & $\begin{array}{l}\text { Accessories for supplying from a compressed air cylinder high-pressure pneumatic } \\
\text { cushions }\end{array}$ & $1 \operatorname{set}(Z)^{*}$ \\
\hline 8 & Compressed air bottle for pneumatic cushions with a capacity of min. 6 litres & $1(\mathrm{Z})^{*}$ \\
\hline 9 & Chainsaw for wood with internal combustion & 1 \\
\hline 10 & Circular saw for steel and concrete with a combustion drive & 1 set \\
\hline 11 & Hardened glass breaker & 1 \\
\hline 12 & Knife for safety belts & 2 \\
\hline 13 & Set of shackles and rope loops for the winch** & 1 set \\
\hline
\end{tabular}




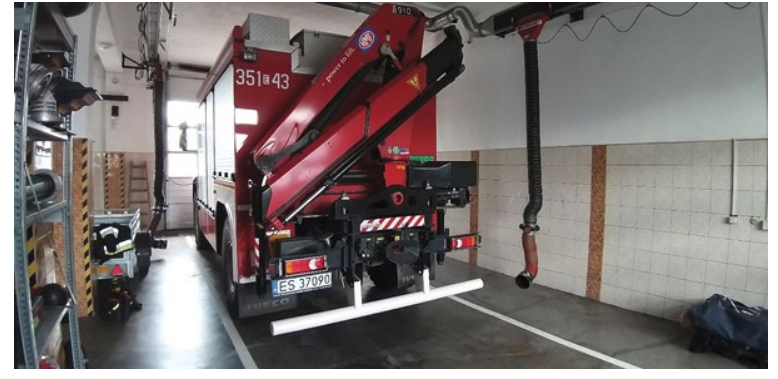

FIGURE 1. A specialized technical rescue vehicle

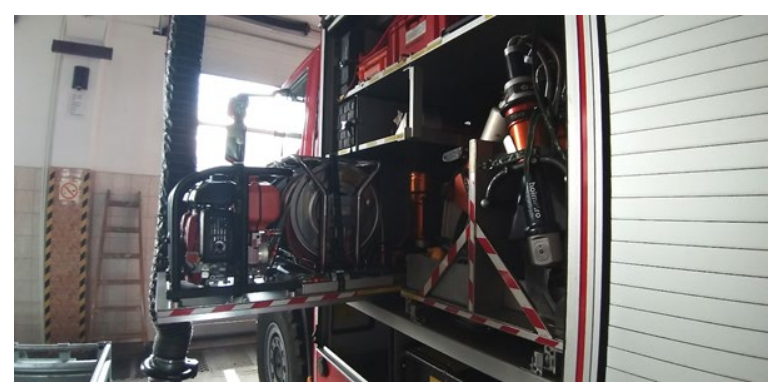

FIGURE 2. A set of hydraulic pumps supplying cutting and spreading devices

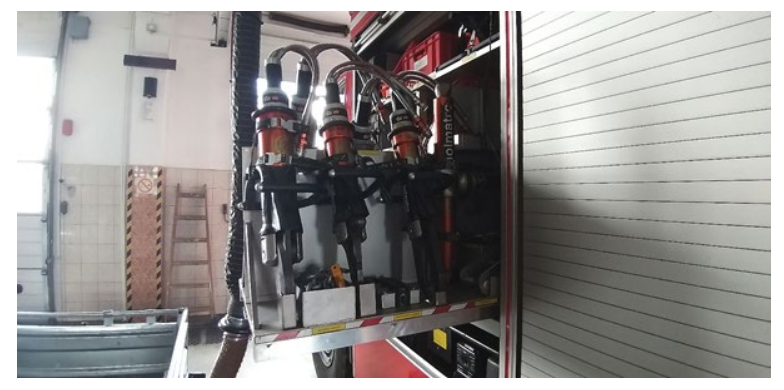

FIGURE 3. Shears and hydraulic thrusters

fied first aid, as well as transferring the victims of the State Medical Rescue out of the danger zone;

c) protection of rescue operations including the protection of rescuers during rescue operations carried out directly in the danger zone and its vicinity;

d) stabilization, cutting, spreading, lifting or moving of construction elements, installations, and devices, as well as parts of objects and natural obstacles and artificial to eliminate or reduce the risk to persons, animals, the environment, infrastructure and other property within the equipment;

e) evacuation of people from places where there is a threat to life and health;

f) evacuation of animals;

g) liquidation or limitation of small, sudden threats caused by hazardous substances or other factors harmful to the environment; h) cooperation with other KSRG entities implementing basic and specialized rescue operations;

i) cooperation with other entities capable of performing technical rescue services [2].

Ability to undertake basic rescue operations in the district comprising at least:

- $80 \%$ of the population inhabited in the district,

- $80 \%$ of the total district area, Maximum in time:

- 15 minutes high-level districts,

- 20 minutes medium level districts,

- 25 minutes low-level districts.

\section{Specialized areas of technical rescue organization}

This scope is carried out by Specialist Groups of Technical Rescue Groups, which equipped with specialized equipment and appropriate training, as well as are in a 24-hour and all-year readiness for action in the primary and specialist range. The area of activity is a district, a voivodship, a county, and it is also possible to operate outside of the state. Dependent on the number and the hardware capabilities of the SGRT group, adequate levels of A and B alert are assigned. Operational readiness of level $A$ defined as the ability to take action (time elapsed from the moment of alerting until the arrival of the alert hosts). Also, by the implementation of the intended tasks by at least six rescuers, while maintaining the alarm time (time elapsed from the moment of being alerted to the moment when the alerts are ready to leave the alarm) no longer than 45 minutes.

When planning the number and deployment of SGRT capable of undertaking technical rescue activities in the field of specialist level A in the voivodships, the ability to undertake rescue operations including at least:

- $80 \%$ of the population inhabited in the voivodship,

- $80 \%$ of the urbanized area of the voivodship, Maximum in time:

- 105 minutes (including 45 min alarming time) for high-risk districts,

- 135 minutes (including 45 min alarming time) for medium-sized districts,

- 165 minutes (including 45 min alarming time) for low-risk districts.

Operational readiness of the $B$ level is defined as the ability to take actions consisting in the implementation of specific tasks, by a team consisting of at least nine rescuers while maintaining an alarm time of no more than 60 minutes. When planning 
the number and deployment of SGRT capable of undertaking technical rescue activities in the field of specialist level $B$ in voivodships, the ability to undertake rescue operations including at least:

- $80 \%$ of the population inhabited in the voivodship,

- $80 \%$ of the urbanized area of the voivodship, maximum time

- 240 minutes (including $60 \mathrm{~min}$ alarming time) for districts with high, medium, and low threat levels [4].

The scope of rescue tasks in the technical area specialized for the level of readiness $A$, in addition to the implementation of tasks at the primary level, is as follows:

1) recognition and identification of threats;

2) securing the zone of rescue operations, including the identification and marking of the danger zone;

3) enabling or disabling installations, devices, and utilities that affect the safety of endangered or injured persons and the safety of rescuers, using valves or fuses that are on the utility installation covered by the rescue operation;

4) prioritization of activities enabling access to and access to endangered or injured persons, including the granting of qualified first aid or their evacuation outside the danger zone, preparation of escape routes for endangered or injured persons and rescuers, providing security to vulnerable or injured persons and rescuers;

5) making passes, arrivals, and commuting to endangered or injured persons together with the removal of obstacles restricting access to them and impeding the performance of medical rescue operations or their movement;

6) evacuation of endangered and injured animals outside the danger zone;

7) assessing the extent of the threat and forecasting its development;

8) lighting the place of the incident and its protection against third parties and performing other activities in the field of logistic security;

9) enabling or disabling installations and devices affecting the size of the danger zone;

10)stabilizing, cutting, spreading, lifting, or transferring structures and devices, as well as parts of natural and artificial objects and obstacles to eliminate or reduce the risk to people, animals, the environment, infrastructure and other property [4].

The scope of rescue tasks in the technical area in the specialized scope for the level of $B$ readiness, in addition to the implementation of tasks at the primary level, is as follows:

1) tasks defined for technical rescue in the scope of the specialist level of readiness $A$;

2) support for SGRT level $A$ activities by additional equipment, in particular, self-propelled cranes [4].

At present, the level of operational readiness A is carried out by the Specialist Technical Rescue Groups: 'BOLESŁAWIEC', 'KUJAWY' (KM PS Włocławek, KP PSP Żnin), 'TARNÓW', 'GDAŃSK', 'BIELSKO-BIAŁA', 'TECHNIKA' (KM PSP Konin, KP PSP Ostrów Wlkp.), 'SZCZECIN' and 'SCHOOL CZĘSTOCHOWA'. The level of operational readiness $A$ and $B$, is implemented by the Specialist Rescue Groups: 'WROCŁAW-4', 'TORUN' (JRG 1 Toruń, KP PSP Świecie), 'LUBLIN 3 PUŁAWY', 'ŚWIEBODZIN', 'ŁÓDŹ', 'KRAKÓW', 'WARSAW-8', 'BRZEG', 'RZESZÓW-3', 'BIAŁYSTOK', 'TCZEW', 'DĄBROWA GÓRNICZA - GLIWICE', 'KIELCE', 'CRANE' (JRG 1 Olsztyn, KP PSP Ostróda) and 'POZNAŃ-7'.

\section{CONCLUSION}

One of the most critical conditions for an efficiently carried out rescue operation is to maintain continuity and consistency of activities throughout their duration, regardless of the interdisciplinary nature of individual elements of the rescue operation [7]. The current organization of rescue systems in Poland allows us to claim that cooperation at the site of the units of the State Medical Rescue and National Rescue and Fire Service takes place at a correct level, which directly translates into efficient operation during events in which various forces and measures involved in the rescue including medical and specialist [8]. Technical rescue is the domain of fire protection units, which in their assumptions are also units supporting the system of State Medical Rescue, with particular emphasis on PSP and those included in KSRG [9]. The use of specialized vehicles and equipment is part of the KSRG tasks, so their presence during events where the use of technical rescue equipment is required is indispensable. Of importance is the emphasis that medical rescue is a narrow and targeted form of help, and as a result, Emergency Medical Teams almost permanently fit into the element of cooperation with KSRG, while handling communication, construction, and other events, in which technical rescue is indispensable. 


\section{REFERENCES}

1. Sever MS, Remuzzi $G$, Vanholder R. Disaster medicine and response: Optimizing life-saving potential. Am J Disaster Med. 2018; 13(4): 253264, doi: 10.5055/ajdm.2018.0305, indexed in Pubmed: 30821339.

2. Rozporządzenie Ministra Spraw Wewnętrznych i Administracji z dnia 3 lipca 2017 r. w sprawie szczegółowej organizacji krajowego systemu ratowniczo-gaśniczego (Dz.U. 2017 poz. 1319).

3. Żuber M, Dziadkiewicz A. Współdziałanie służb, inspekcji i straży na szczeblu powiatu w sytuacjach nadzwyczajnych zagrożeń. Historia i Polityka. 2018(23 (30)): 69, doi: 10.12775/hip.2018.005.

4. Zasady organizacji ratownictwa technicznego w krajowym systemie ratowniczo gaśniczym. Komenda Główna Państwowej Straży Pożarnej. Warszawa 2013.

5. Program szkolenia z ratownictwa technicznego realizowanego przez KSRG w zakresie podstawowym. Komenda Główna Państwowej Straży Pożarnej. Warszawa 2016.
6. Podlasiński R, Karabin P. Skrypt do szkolenia z ratownictwa technicznego realizowanego przez KSRG w zakresie podstawowym. KGPSP, Warszawa 2018.

7. Szarpak Ł. Centrum powiadamiania ratunkowego elementem systemu bezpieczeństwa publicznego. Zeszyty Naukowe/Wyższa Szkoła Oficerska Wojsk Lądowych im. gen. T. Kościuszki. 2011; 161(3): 389-396.

8. Gawlowski P, Iskrzycki L. The preparation and usage of public rescue units cooperating with the national medical rescue system towards actions taken on the spot of a disaster - an analysis of the issue based on the example of Wroclaw and Lower Silesia. Disaster and Emergency Medicine Journal. 2017; 2(1): 27-32, doi: 10.5603/ demj.2017.0005.

9. Ustawa z dnia 8 września 2006 r. o Państwowym Ratownictwie Medycznym (Dz.U. 2006 nr 191 poz. 1410). 